\section{Retention of a passive avoidance response as a function of the intensity and duration of electric shock}

\author{
ROBERT ADER*, J. A. W. M. WEIJNEN, and PETER MOLEMAN \\ Rudolf Magnus Institute for Pharmacology \\ University of Utrecht-Medical Faculty, Utrecht, The Netherlands
}

Upon leaving an elevated runway to enter a darkened chamber, different groups of rats were given a single electric shock of $0.125,0.250$, or $0.500 \mathrm{~mA}$ for 1,3 , or 9 sec. Retention trials, during which latency to enter the darkened chamber and defecation were recorded, were given immediately $(30 \mathrm{sec})$ or 3 , 24 , or $48 \mathrm{~h}$ after the shock trial. Latency and defecation were directly related to both the intensity and duration of the electric shock. No interaction between shock intensity and duration was observed. Response latency was inversely related to the retention interval and, although there was more defecation during the $3-\mathrm{h}$ than during the immediate retention test, this could be interpreted as a recency effect rather than as the incubation of fear.

The one-trial passive avoidance paradigm provides relatively precise control over the time at which learning occurs. This property favors the use of this test situation in the study of memory processes and of the effects of interpolated treatments (e.g., electroconvulsive shock and pharmacologic agents) on these processes. With respect to memory processes, per se, many authors have decried the paucity of parametric data which would, presumably, clarify some of the inconsistencies reported in the literature. For example, increasing the intensity of electric shock reliably elicits increasing response latencies (e.g., Clark, 1967; Essman \& Sudak, 1964; Z ammit-Montebello, Black, Marquis, \& Suboski, 1969); the relationship between response latency and the retention interval, however, is not nearly so consistent. Monotonically increasing (Allen \& Mitcham, 1970; McGaugh, 1966) and decreasing (Clark, 1967) functions, inverted U-shaped curves (e.g., Geller, Jarvik, \& Robustelli, 1970 ; Zammit-Montebello et al, 1969) and bimodal functions (Irwin \& Benuazizi, 1966; Irwin, Benuazizi, Kalsner, \& Curtis, 1968; Robustelli, Geller, \& Jarvik, 1970; Zerbolio, 1969) have been reported.

In studying the effects of pharmacologic stimulation of the central nervous system and of electroconvulsive shock on the retention of passive avoidance behavior, there has been a

*This research was conducted while the senior author was on leave of absence from the University of Rochester School of Medicine and Dentistry, Rochester, N.Y. 14642 and supported by U.S.P.H.S. Grant 1-K05-MH06318 from the National Institute of Mental Health. concentration on the deleterious forgetting or interference with the consolidation of memory traces. The present study was designed to examine the role of the intensity and duration of electric shock in determining the retention of a passive avoidance effects of such treatments; that is, on response. It was necessitated by the need and would, hopefully, provide the data required to select levels of aversive stimulation that would be sensitive to interpolated treatments with the potential to facilitate as well as to interfere with the retention of a passive avoidance response acquired in a single trial.

\section{METHOD}

The Ss were male Wistar rats weighing 180 to $210 \mathrm{~g}$. The animals were maintained five per cage under ad lib food and water. The lights were on from 5 a.m. to 7 p.m., and all observations were made between 1:30 and $4: 30$ p.m.

Passive avoidance conditioning took place in a dark sound-attenuated room. The apparatus (Fig. 1) was a $40-\mathrm{cm}^{3}$ Lucite chamber with black walls. The floor of the box was constructed of $4-\mathrm{mm}$ stainless steel rods spaced $1.4 \mathrm{~cm}$ apart at the centers; the top of the chamber was open except for a 2.5-cm "lip" extending around the perimeter and into the center. The front wall of the apparatus was situated at the edge of a $\mathrm{table}$, and a $6-\mathrm{cm}-\mathrm{wide}$ wire-mesh-covered runway extended $25 \mathrm{~cm}$ from the center of this wall on

a plane with the grid floor. Passage

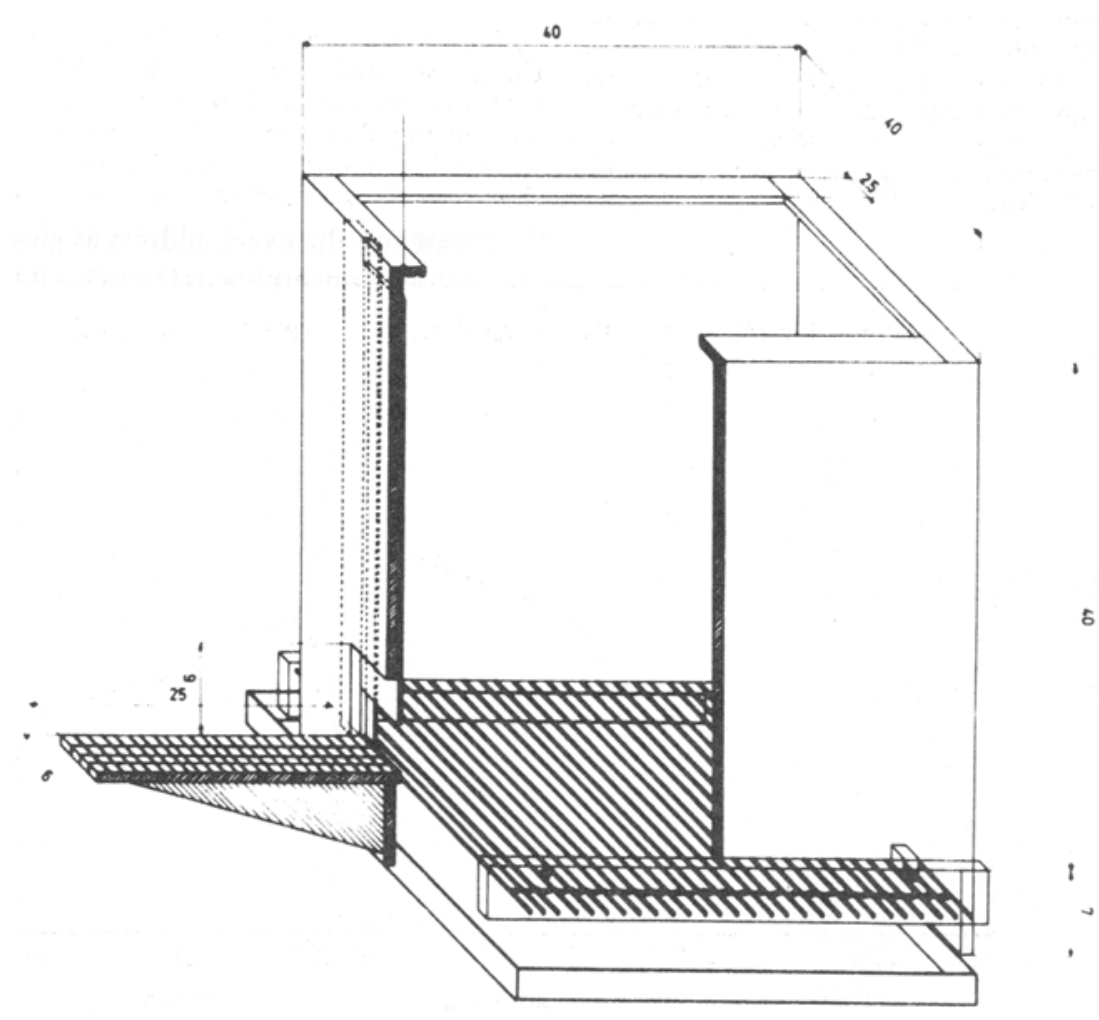

Fig. 1. Apparatus for passive avoidance conditioning in the rat. (The details of construction are such that the front wall containing the elevated runway used in the present study can be removed and replaced with a unit containing a smaller, lighted chamber, or with a solid wall to be used with a "step-down" procedure.) 


\begin{tabular}{|c|c|c|c|c|c|c|c|c|c|c|c|c|c|}
\hline \multirow{3}{*}{$\begin{array}{c}\text { Shock } \\
\text { Dura- } \\
\text { tion } \\
\text { (Sec) }\end{array}$} & \multirow[b]{3}{*}{ Statistic } & \multicolumn{3}{|c|}{0} & \multicolumn{6}{|c|}{$\begin{array}{l}\text { Retention Interval (Hours) } \\
3\end{array}$} & \multicolumn{3}{|c|}{48} \\
\hline & & \multicolumn{12}{|c|}{ Shock Intensity (mA) } \\
\hline & & .125 & .250 & .500 & .125 & .250 & .500 & .125 & .250 & .500 & .125 & .250 & .500 \\
\hline 1 & $\begin{array}{l}\text { Percent }>\text { Median } \\
\text { Median }\end{array}$ & $\begin{array}{l}20.0 \\
28.0\end{array}$ & $\begin{array}{l}50.0 \\
78.0\end{array}$ & $\begin{array}{r}80.0 \\
300.0\end{array}$ & $\begin{array}{r}0.0 \\
15.0\end{array}$ & $\begin{array}{l}40.0 \\
76.5\end{array}$ & $\begin{array}{r}60.0 \\
126.5\end{array}$ & $\begin{array}{l}0.0 \\
7.0\end{array}$ & $\begin{array}{l}10.0 \\
16.5\end{array}$ & $\begin{array}{r}50.0 \\
137.5\end{array}$ & $\begin{array}{l}0.0 \\
5.0\end{array}$ & $\begin{array}{l}10.0 \\
46.5\end{array}$ & $\begin{array}{r}60.0 \\
252.5\end{array}$ \\
\hline 3 & $\begin{array}{l}\text { Percent > Median } \\
\text { Median }\end{array}$ & $\begin{array}{l}30.0 \\
41.5\end{array}$ & $\begin{array}{r}80.0 \\
300.0\end{array}$ & $\begin{array}{r}80.0 \\
300.0\end{array}$ & $\begin{array}{l}20.0 \\
52.5\end{array}$ & $\begin{array}{r}60.0 \\
158.0\end{array}$ & $\begin{array}{r}90.0 \\
300.0\end{array}$ & $\begin{array}{r}10.0 \\
8.0\end{array}$ & $\begin{array}{r}60.0 \\
198.0\end{array}$ & $\begin{array}{r}80.0 \\
300.0\end{array}$ & $\begin{array}{r}10.0 \\
6.0\end{array}$ & $\begin{array}{l}40.0 \\
48.0\end{array}$ & $\begin{array}{r}80.0 \\
300.0\end{array}$ \\
\hline 9 & $\begin{array}{l}\text { Percent }>\text { Median } \\
\text { Median }\end{array}$ & $\begin{array}{l}50.0 \\
89.5\end{array}$ & $\begin{array}{r}90.0 \\
300.0\end{array}$ & $\begin{array}{l}100.0 \\
300.0\end{array}$ & $\begin{array}{l}30.0 \\
54.5\end{array}$ & $\begin{array}{r}90.0 \\
300.0\end{array}$ & $\begin{array}{r}90.0 \\
300.0\end{array}$ & $\begin{array}{l}20.0 \\
20.0 \\
\end{array}$ & $\begin{array}{r}90.0 \\
300.0 \\
\end{array}$ & $\begin{array}{r}80.0 \\
300.0 \\
\end{array}$ & $\begin{array}{l}10.0 \\
41.0\end{array}$ & $\begin{array}{l}40.0 \\
75.0\end{array}$ & $\begin{array}{r}90.0 \\
300.0 \\
\end{array}$ \\
\hline
\end{tabular}

from the elevated runway into the box was via a $6-\mathrm{cm}^{2}$ opening controlled by a guillotine door. The shock box remained dark, while a 25-W lamp was fixed $40 \mathrm{~cm}$ above the center of the elevated runway.

Adaptation trials were run to achieve a stable baseline performance level. On the first day of adaptation, animals were placed inside the box, with closed door, for a period of $2 \mathrm{~min}$. This was followed by a single trial in which the rat was placed on the elevated runway (facing away from the door) and allowed to enter the box. Upon entry (all four feet), the guillotine door was lowered, leaving just enough space for the rat's tail. On Day 2, the animals were given three such trials, during which the latency to enter the box was recorded. Animals remained in the box for $10 \mathrm{sec}$; the interval between trials was approximately $2 \mathrm{~min}$. On the third of these trials, the animals received scrambled electric shock through the grid floor of the cage immediately after entering. Shock was produced by a $500-\mathrm{V}$ ac source delivered through a variable series resistor. The shock intensities were $0.125,0.250$, or $0.500 \mathrm{~mA}$, presented continuously for 1,3 , or 9 sec. Total time in the box, however, remained $10 \mathrm{sec}$. Following each trial, animals were returned to their home cage, located outside the experimental room.

Retention was tested when the animals were again placed on the elevated runway either immediately (after $30 \mathrm{sec}$ in the home cage) or 3 , 24 , or $48 \mathrm{~h}$ after the shock trial. Although no electric shock was to be presented, the auditory stimulation provided by the shock scrambler remained on. Defecation on the elevated runway and latency to enter the darkened box (to a maximum of $300 \mathrm{sec}$ ) were recorded. There were, then, 36 cells in this 3 by 3 by 4 factorial design, and one rat per cell was observed in each of the 10 weekly replications. At each retention interval there were six additional animals that

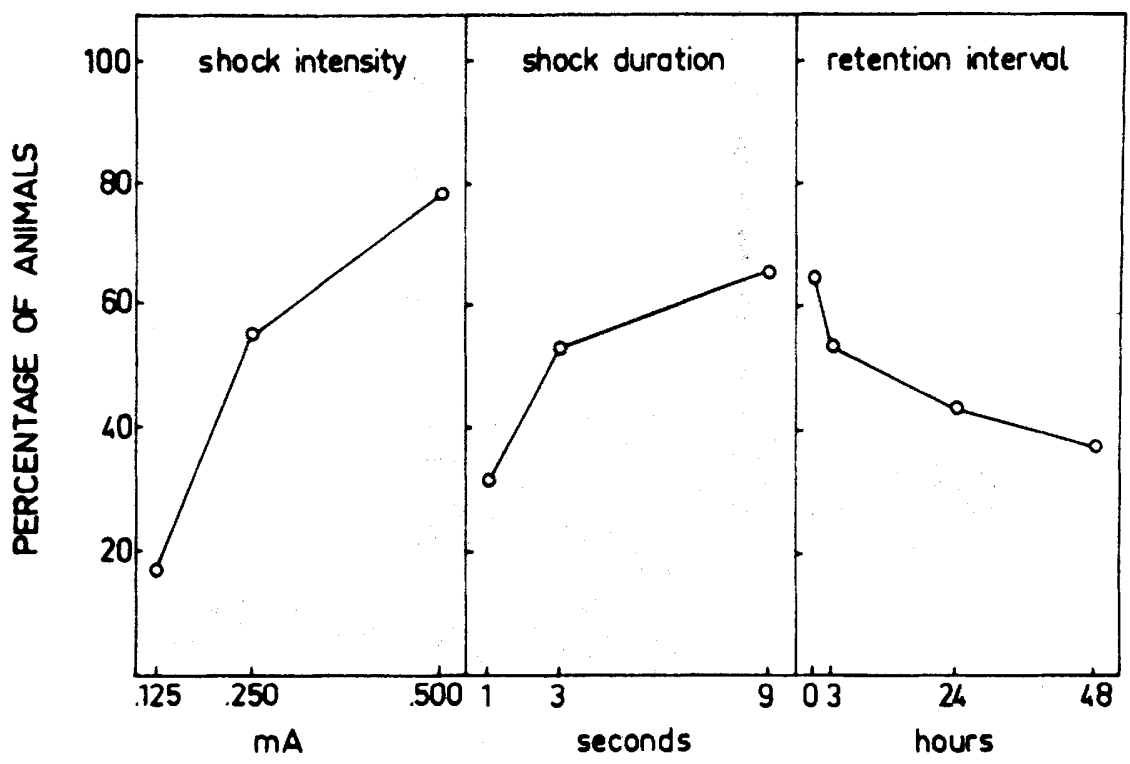

Fig. 2. Percentage of animals with retention latencies greater than the overall median latency as a function of shock intensity, shock duration, and retention interval. were tested without having received electric shock. A final week of testing was required in order to replace animals eliminated because of experimental errors.

\section{RESULTS}

Table 1 contains the median latencies and the percentage of animals with latencies greater than the overall median for all groups. Parametric analyses of these data did not seem appropriate since 139 of the 360 animals $(46.3 \%)$ were assigned retention latencies of greater than $300 \mathrm{sec}$, which was the arbitrarily chosen limit. None of the nonshocked animals remained on the elevated runway; the median latencies were 7.0, $6.0,4.5$, and $5.0 \mathrm{sec}$ for the groups tested at $0,3,24$, and $48 \mathrm{~h}$, respectively.

For purposes of statistical analysis, the animals were divided into those with latencies greater and those with latencies less than the overall median (94.5 sec), and an analysis of variance for dichotomous data extrapolated from Winer (1962) was used. Although more conservative than an analysis of ranks, this procedure would permit a more direct assessment of interaction effects. The only significant values of $F$, however, were for the main effects of shock intensity $(F=74.08$, df $=2 / 324, p<.01)$, shock duration $(\mathrm{F}=21.21, \mathrm{df}=2 / 324, \mathrm{p}<.01)$, and retention interval ( $F=7.64$, $\mathrm{df}=3 / 324, \mathrm{p}<.01)$. These effects (which were also statistically significant by Kruskal-Wallis analyses of median latencies) are shown in Fig. 2.

Each increase in the intensity of electric shock resulted in an increase in latency independent of the duration of shock or the time that had elapsed since the shock had been experienced. Similarly, there was a direct relationship between shock duration and retention latency, although the difference between the $3-$ and 9 -sec groups was significant only at the .10 level $\left(x^{2}=2.91\right)$.

Animals tested for retention immediately $(30 \mathrm{sec})$ after the shock trial showed the longest latencies, and the number of animals in this 


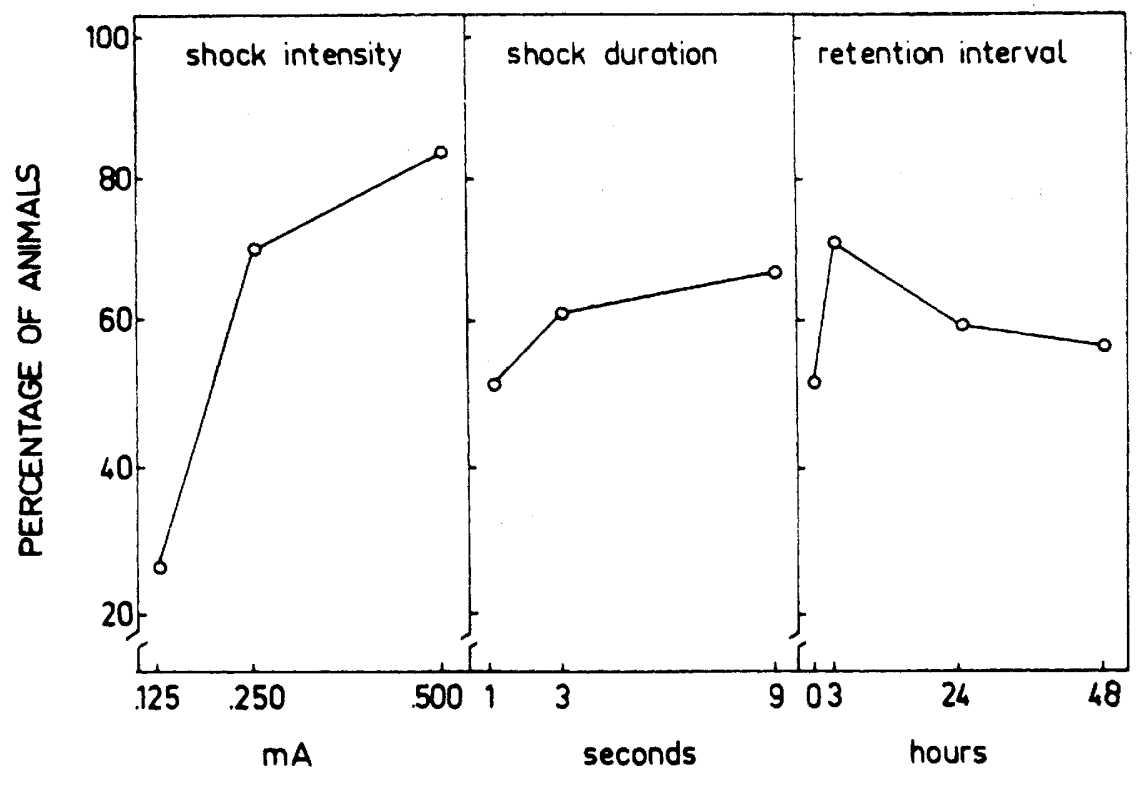

Fig. 3. Percentage of animals defecating during tests of retention of a passive avoidance response as a function of shock intensity, shock duration, and retention interval.

group with latencies greater than the overall median was significantly greater than those tested at 24 and $48 \mathrm{~h}$. Animals tested $3 \mathrm{~h}$ after the shock trial differed only from those tested at $48 \mathrm{~h}\left(\mathrm{x}^{2}=3.79\right)$. The 24 - and 48 -h groups did not differ significantly.

An analysis of the defecation data in terms of scores greater or less than the overall median (equivalent to animals that did and did not defecate) yielded results similar to that for latencies. These data are shown in Fig. 3.

With each increase in shock intensity, there was a significant increase in the number of animals defecating $(\mathrm{F}=60.76, \quad \mathrm{df}=2 / 324$, $\mathrm{p}<.01)$. There was a similar relationship for shock duration $(\mathrm{F}=4.26, \mathrm{df}=2 / 324, \mathrm{p}<.05) ;$ in this case, however, only the difference between the 1 - and 9 -sec groups was significant $\left(x^{2}=5.63\right)$.

Defecation also varied as a function of the retention interval $(F=3.15$, $\mathrm{df}=3 / 324, \mathrm{p}<.05)$. In this instance, fewer of the animals tested immediately after the shock trial defecated than did animals tested $3 \mathrm{~h}$ later $\left(x^{2}=6.02\right)$. Animals tested $3 \mathrm{~h}$ after the shock trial also showed more defecation on the elevated runway than those tested at 24 and $48 \mathrm{~h}$, but only the latter difference approached statistical significance $\left(x^{2}=2.93\right.$, $\mathrm{p}<.10$ ).

\section{DISCUSSION}

In keeping with the results of previous studies (Clark, 1967; Essman \& Sudak, 1964; Zammit-Montebello et al, 1969), our data showed that yet available. Another possibility is that, for the present experimental conditions, we inadvertently selected an inappropriate or insufficient range of postshock intervals at which to test for the retention of the avoidance response.

Unlike the effects of shock intensity and shock duration, varying the retention interval did not have quite the same effect on defecation scores as on response latencies. The defecation data could be interpreted as the reflection of an incubation effect. However, since virtually all animals defecated immediately after experiencing electric shock, it might be more parsimonious to attribute the observed function to a decreased capacity to defecate in the animals tested for retention immediately (30 sec) after the shock trial.

The general parallel between defecation scores and response latencies raises the question of the extent to which performance in the passive avoidance situation represents (in addition to whatever else is being learned) the conditioning of an emotional response (fear) which is independently sensitive to situational factors as well as to the parameters of aversive stimulation. For example, a dissociation between heart rate and overt behavioral responses has been observed in both active (Werboff, Duane, \& Cohen, 1964) and passive (Hine \& Paolino, 1970) avoidance situations. Behavior presumed to reflect the consolidation of memory traces (e.g., the observation of an incubation effect) could, then, actually reflect an interaction between the relative strength or magnitude of different conditioned response tendencies with different temporal characteristics.

\section{REFERENCES}

electric shock, and our data provided no evidence for an incubation effect in passive avoidance performance. Any combination of several sources of variability could have accounted for this failure to observe such complex functions. As noted above, nearly half of our population had response latencies greater than the arbitrarily chosen limit of $300 \mathrm{sec}$, which would have acted to reduce the sensitivity of our measure. These animals showed maximal latencies even though the intensities of electric shock used in the present experiment were among the lowest reported in this literature, suggesting that situational factors may also have contributed to these results. Preliminary observations with a step-down procedure in this same apparatus yielded a totally different magnitude of response latencies. Unfortunately, however, parametric data on such situational factors are not
ALLEN, J. D., \& MITCHAM, J. C. The time course of fear incubation following single-trial passive-avoidance training. Psychonomic Science, $1970,20,169-170$.

C L A R K, R. Retention of a passive-avoidance response in mice. Psychonomic Science, 1967, 7, 29-30.

ESSMAN, W. B., \& SUDAK, F. N. Single-trial avoidance conditioning in rats. Psychological Reports, 1964, 15, 775-783.

GELLER, A., JARVIK, M. E., \& ROBUSTELLI, F. Incubation and the Kamin effect. Journal of Experimental Psychology, 1970, 85, 61-65.

HINE, B.. \& PAOLINO, R. M. Retrograde amnesia: Production of skeletal but not cardiac response gradient by electroconvulsive shock. Science, 1970, 169, 1224-1226.

IRWIN, S., \& BENUAZIZI, A. Pentylenetetrazol enhances memory function. Science, 1966, 152, 100-102.

IRWIN, S., BENUAZIZI, A., KALSNER, S., \& CURTIS, A. One trial learning in the mouse. Psychopharmacologia, 1968, 12 , 286-302.

McGAUGH, J. L. Time-dependent processes in memory storage. Science, $1966,153$. 1351-1358. 
ROBUSTELLI, F., GELLER, A., \& JARVIK, M. E. Biphasicity of the incubation curve. Psychonomic Science, $1970,20,129-130$.

WERBOFF. J., DUANE, D., \& COHEN, B. D. Extinction of conditioned avoidance and heart rate responses in rats. Journal of Psychosomatic Research, 1964, 8, 29-33.

WINER, B. J. Statistical principles in experimental design. New York: McGraw-Hill, 1962.

ZAMMIT-MONTEBELLO, A., BLACK, M. MARQUIS, H. A., \& SUBOSKI, M. D.
Ir.cubation of passive avoidance in rats: Shock intensity and pretraining. Journal of Comparative \& Physiological of Comparative \& Phy siology, 1969, 69, 579-582.

ZERBOLIO, D. J. Memory storage: The first posttrial hour. Psychonomic Science, $1969,15,57-58$. 